\title{
Erratum to: Effector Translocation: Cya Reporter Assay
}

\section{Suma Chakravarthy, Bethany Huot, and Brian H. Kvitko}

\section{Erratum to:}

Chapter 33 in: Laure Journet and Eric Cascales (eds.), Bacterial Protein Secretion

Systems: Methods and Protocols, Methods in Molecular Biology, vol. 1615, https://doi.org/10.1007/978-1-4939-7033-9_33

An error was observed in Step 2 of section 3.3. Direct cAMP Assay of this chapter. The same was replaced with the correction below.

2. Vortex the frozen tubes rapidly so the copper BBs grind the tissue into a fine powder. Keep the tubes with powdered plant material frozen in liquid nitrogen until immediately prior to adding $0.1 \mathrm{M} \mathrm{HCl}$ in Step 3. Ground tissue can also be frozen at $-80^{\circ} \mathrm{C}$ until use. (See Note 14). 